\title{
Handling Lithium-Ion Batteries in Electric Vehicles: Preventing and Recovering from Hazardous Events
}

\author{
Roeland Bisschop (D), Ola Willstrand and Max Rosengren, Department of \\ Safety Research, RISE Research Institutes of Sweden, Borås, Sweden
}

Received: 24 September 2019/Accepted: 27 August 2020

\begin{abstract}
The demand for lithium-ion battery powered road vehicles continues to increase around the world. As more of these become operational across the globe, their involvement in traffic accidents and incidents is likely to rise. This can damage the lithium-ion battery and subsequently pose a threat to occupants and responders as well as those involved in vehicle recovery and salvage operations. The project this paper is based on aimed to alleviate such concerns. To provide a basis for fire safety systems to be applied to damaged EVs, hazards have been identified and means for preventing and controlling lithium-ion battery fires, including preventive measures during workshop and salvage activities were studied. Tests were also performed with fixed fire suppression systems applying suppressant inside traction batteries which showed to improve their safety.
\end{abstract}

Keywords: Lithium-ion batteries, Electric vehicles, Risk management, Fire testing, Vehicle fire safety, Fire suppression

\section{Introduction}

The demand for electric vehicles (EVs) continues to increase around the world. They have proven to reduce emissions and operate more efficiently than vehicles driven by fossil-fuels. In part this is made possible due to significant technological advances in energy storage systems, specifically those that are part of the lithiumion family. Their unmatched properties such as high cycle life, high energy density, and high efficiency makes them suitable for automotive applications [1].

As more lithium-ion battery (LIB) powered road vehicles become operational across the globe, their involvement in traffic accidents is likely to rise. There is a risk, as in conventionally fueled vehicles, that the on-board energy storage system becomes a hazard to the safety of those involved in, or responding to, accidents. While the risks associated with conventional vehicles are well-defined and generally accepted by society; time and education are needed to achieve this comfort level for LIB powered road vehicles.

\footnotetext{
* Correspondence should be addressed to: Roeland Bisschop, E-mail: roeland.bisschop@ri.se
} 
The project this paper is based on aimed to alleviate such concerns. Its role was to provide a basis for fire safety systems to be applied to damaged EVs. Of interest were relevant risk assessment routines and to evaluate what role integrated fire safety systems can play in providing greater occupant protection. To form this basis, the study combined literature studies with risk workshops, carried out by vehicle manufacturers, fire safety experts, vehicle workshops and fire suppression system manufacturers, as well as physical testing of integrated fire suppression systems.

\section{The Ongoing Electrification of Road Vehicles}

An increasing number of road vehicles is being electrified with the aid of lithiumion traction batteries [1]. They may either be a major source for the vehicle's traction force; hence they are referred to as traction batteries. Or they may play a more subtle role, for example in a micro-hybrid system [2], where it assists traditional propulsion systems by enabling start/stop systems for example. Their increasing popularity is linked to some significant advantages of electrification. Electrified road vehicles have proven to reduce emissions and operate more efficiently than vehicles driven by fossil-fuels. A major issue with conventional powertrains lies in their source of power, combustion of non-renewable fuels. This process is not very efficient. Even the most advanced internal combustion engines operate below 50\% efficiency [3]. Electric motors, however, operate at around $95 \%$ efficiency. [2, 3].

This, combined with breakthroughs in developing lithium-ion batteries, contributes to more electric vehicles being on the road. Data from the International Energy Agency up to 2019, presented in Fig. 1, shows that most of the passenger cars in the world can be found in the Peoples Republic of China (henceforth referred to as China) and the United States (US) [4]. Coming in third place is the European Union [4, 5]. In 2019, approximately half of all electric passenger cars in the world could be found driving around in China. Other vehicle types, such as buses are experiencing similar trend. Currently, this shift is particularly evident for

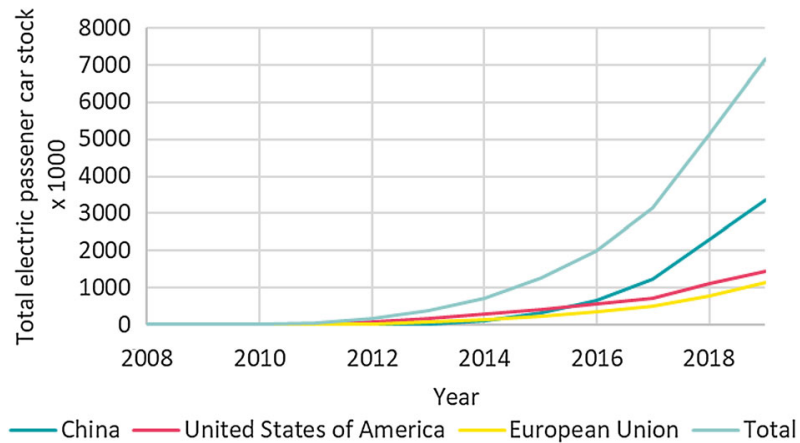

Figure 1. The uptake of electric passenger cars is dominated by China and US [6], followed by the European Union [5]. 
public transportation solutions in large cities, influenced by cost and weight of lithium-ion battery packs. Specifically, smaller batteries can be used in local city traffic as there are short routes with frequent stops. In contrast, long haul buses, would either require very large and thus heavy batteries or require continuous charging.

Another development is in the area electric two/three wheelers, whose total numbers have increased quickly since 2017. Examples are shared electric scooters, electric bicycles and electric mopeds. Their numbers have risen significantly since 2017, being estimated to have reached a global stock of 350 million units [6].

\section{Traction Batteries}

This paper focuses on lithium-ion batteries that significantly contributes to a vehicle's automotive force, namely the traction battery. The traction battery is of interest as it is one of the most challenging fire risks for first responders and vehicle workshops to manage today [7]. In addition, their high voltage (300-1000 V) and large amount of energy stored (up to $100 \mathrm{kWh}$ ) can yield a significant safety hazard. Figure 2 gives a simplified illustration of such a traction battery. They can be made up of many battery cells. The lithium-ion battery cell enclosure consists of one or several electrochemical cell units. Their voltage, which is usually around $4 \mathrm{~V}$, varies depending on the cathode and anode material chosen. This is also true for other properties related to their capacity, cost, and safety. The battery cells by themselves are not of much use for road vehicles. However, by connecting many cells in series and/or parallel, their final output can be scaled. The next scale in traction batteries for road vehicles is usually that of the battery module. The number of cells per module varies but generally adds up to less than $60 \mathrm{~V}$ of direct

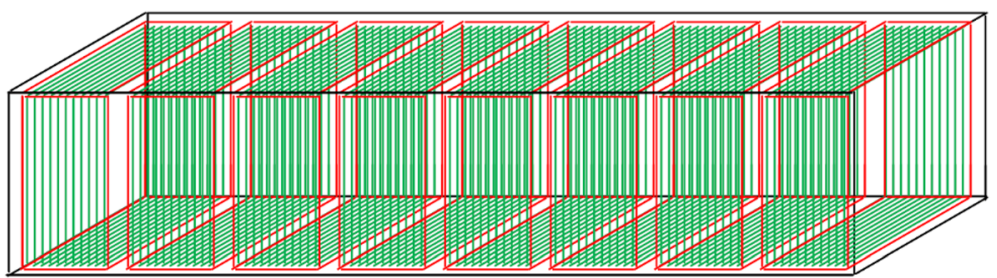

Pack 300 V - 1000 V

Module $<60 \mathrm{~V}$

Cell $\sim 4 \mathrm{~V}$

Figure 2. General construction of a traction battery.

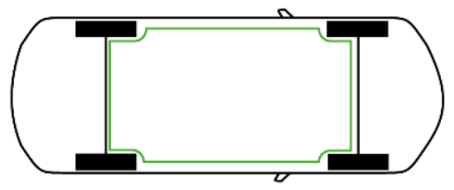

Figure 3. "Floor" solution. 


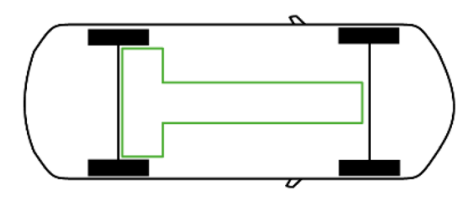

\section{Figure 4. "T" solution.}

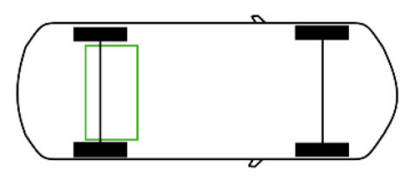

\section{Figure 5. "Rear"' solution.}

current (DC) per module. Voltages greater than $30 \mathrm{~V}$ of alternating current (AC) or $60 \mathrm{~V}$ DC are classified as high voltages within the vehicle industry $[8,9]$. Such voltage levels are generally considered as being lethal and require more stringent safety procedures to be followed [10]. Restricting the voltage of battery modules therefore contributes to facilitate safe handling and shipping. Finally, the battery modules are connected with auxiliary and safety equipment inside a protective enclosure to form the final battery pack.

The battery pack geometry, its position and the structural design of the vehicle are all relevant design parameters when integrating the battery pack in the vehicle [11]. A common approach is to install the battery pack inside stiffened and reinforced compartments or areas less prone to be affected in crash conditions [11]. The latter is sometimes referred to as a vehicle's "safe zone" [12]. This zone refers to the area in the center of the chassis, between the wheel shafts. For passenger cars there are three main configurations in which this space is used by the traction battery. Most common are the " $T$ " and "Floor" configurations [13] as shown in Figs. 3 and 4, respectively. Small vehicles or hybrids normally require less energy storage capacity. In those cases, sometimes the "Rear" configuration is considered. Here the battery pack is in the rear of the vehicle and stacked upwards, see Fig. 5.

Buses do not necessarily follow the configurations presented for passenger cars. Rather than integrating the battery pack underneath the vehicle, bus manufacturers such as Volvo Bus, Solaris, BYD and VDL opt for placing them on top of some of their vehicles, as seen in Fig. 6. Placing the battery on top of the vehicle namely requires fewer modifications to be made to existing buses. Other benefits include the fact that the batteries are easier exposed to air, allowing them to be cooled by the moving vehicle, along with them being more easily accessible for some charging systems, and that the maximum amount of space is made available to passengers. However, a disadvantage is the higher center of gravity. 


\section{Fire Safety of Electric Road Vehicles}

The fire safety of energy carriers is related to their fuel source. For conventional vehicles, a common fuel is gasoline for example. This fuel can be extremely dangerous if not handled or stored safely. The same principle applies to lithium-ion batteries, the fuel source for most EVs today. Burning LIBs have some distinct features, such as thermal runaway and ventilated flammable and toxic gases. This gives that although burning EVs pose a different risk, it may not be greater than that posed by the conventional vehicles we have gotten used to.

The fire safety of vehicles, not only EVs, can be enhanced through consideration of preventive and recovery measures. A method considered in the paper is the so-called bow-tie method, which is illustrated in Fig. 7. Here a qualitative version of the bow-tie method is employed to communicate the risk of a LIB fire in an EV to the reader, focusing on potential barriers to threats and consequences. The bow-tie shown in Fig. 7 converges on the top event: the moment control is lost [21]. In this paper this event corresponds to a fire breaking out inside the LIB of an EV. This could result in a cascading effect. For example, from a fire spread perspective, the problem may first spread throughout the LIB, followed by vehicle, and then any flammable materials nearby. In turn, as the fire size increases, so

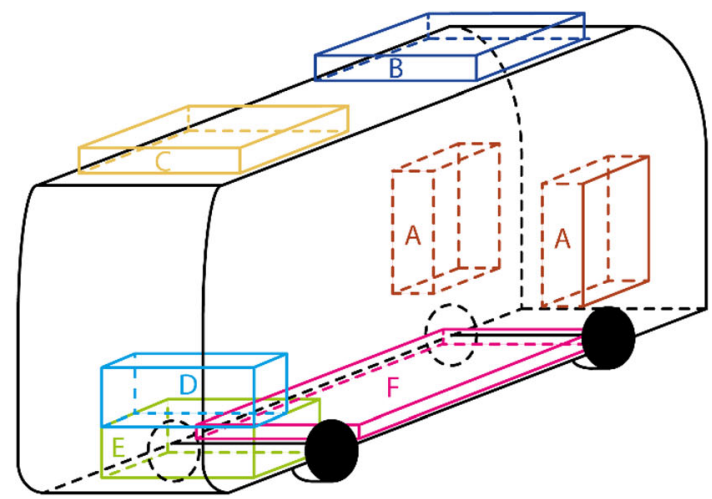

\begin{tabular}{|c|c|}
\hline BYD K9 & $A+C+E[14$ \\
\hline Volvo 7900 & $C[15]$ \\
\hline VDL Citea & B [16] \\
\hline Solaris Urbino & B [17] \\
\hline Optare Versa & $D+E[18]$ \\
\hline $\begin{array}{l}\text { Proterra } \\
\text { Catalyst }\end{array}$ & $F[19,20]$ \\
\hline
\end{tabular}

Figure 6. Battery packs in electric buses.

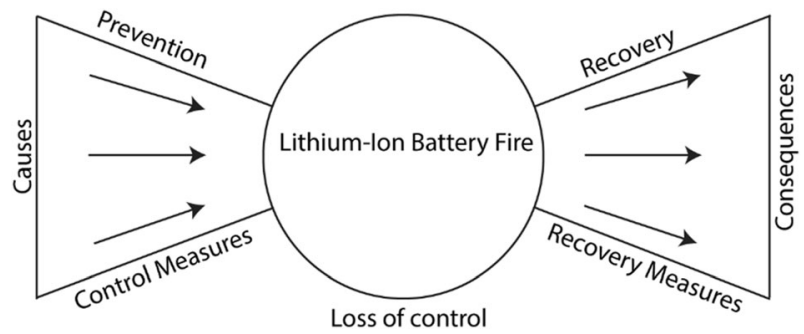

Figure 7. The bowtie model that is considered to study the fire safety of EVs. 
do its environmental consequences. It is thus crucial that these cascading effects are either prevented by removing events that may cause the lithium-ion battery fire. The other side of the bowtie assumes that there is already exists a lithium-ion battery fire. At this point, the focus shifts to reducing the negative outcome and regain control over it. Both sides of this bowtie model are discussed in this section.

\subsection{Hazards when Handling Damaged EVs}

Collision or crash has the potential to cause the LIB to burn as shown by Bøe [22]. By dropping a custom-made EV from a height of $20 \mathrm{~m}$ they showed that certain impact conditions can result in a large amount of smoke being released from the battery followed by a fire. This potential was also observed in the field. Examples of this are the EV crashes in Ft. Lauderdale, USA [23, 24], and South Jordan, USA [25]. The fire size which may result from such an event is not different of one for a conventional vehicle, however. A review of battery fires in electric vehicles by Sun et al. [26] showed that the peak heat release rate for an EV is around $6.1 \pm 1.7 \mathrm{MW}$. This is comparable to statistics for (older) conventional vehicles with a peak heat release rate around $5 \mathrm{MW}$ [27]. These fires are hard to extinguish however, requiring more suppressant than what is needed for conventional vehicles. For example, between 750 and $1100 \mathrm{~L}$ of water and foam was used to suppress the Ft. Lauderdale fire. Long et al. found that in some cases the amount of water and time needed to suppress an EV fire could be in the range of $10,000 \mathrm{~L}$ and a quenching time of $60 \mathrm{~min}$ [28], significantly more than what is normally needed for fighting conventional vehicle fires which is normally suppressed in 5 min [29].

Once the fire has been extinguished there may still be stranded energy in the lithium-ion battery. This can be problematic, not only for first responders but also for towing and workshop activities. This was shown by the Ft. Lauderdale crash mentioned [23, 24], where the battery reignited as the crashed vehicle was being removed from the scene. Although quickly extinguished, the fire ignited again upon arrival to the salvaging yard. The South Jordan case also suffered from a reignition event, the same day at the impound lot and 5 days after the crash [25]. Arguably the most infamous example, is the Chevrolet Volt fire in 2011 [30]. Here the National Highway Traffic Safety Administration (NHTSA) performed a side pole impact test to observe the extent of damage done to the LIB of a Chevrolet Volt. Significant damage to the vehicle was observed, yet intrusion of the battery pack went unnoticed at the time of the test. The vehicle was subsequently observed for 30 days, after which it caught fire, likely due to fire hazard produced through contact between leaked coolant and the battery. Submersion of an EV in other conductive media such as seawater or contaminated water have also caused battery fires. One example of this are fires in a hybrid bus in the USA [31]. Debris and moisture was able to accumulate near the rooftop mounted LIB, which caused the LIB to discharge its energy, generate smoke as well as melt and char its internal components. Fire in two electric buses in China due to heavy rain fall [32] may be considered as another example. Although the exact cause is unknown, 
moisture combined with (conductive) debris can result in a discharging battery and heat generation when allowed to penetrate the lithium-ion battery system.

Handling damaged EVs may also pose electrical hazards under certain circumstances. The general risk to personal safety is low as it is unlikely that an EV chassis is exposed to current from the high-voltage system. A so-called floating ground that the battery system employs, should guarantee that there is no connection to the chassis. In addition, an EV will automatically disconnect the battery system from the powertrain based on a sensed level of impact or abuse of the LIB, or from isolation faults. As a result, touching a live part of the high voltage system will normally not cause current to enter a person's body. However, this will be possible when a person is in direct contact with the plus and minus terminals of the battery [12]. Note that contact to a bipolar contact with exposed live parts, e.g. due to degradation of insulation materials, can also result in electric shock.

\subsection{Prevention and Recovery when Handling Damaged EVS}

One important thing to consider in all activities with LIBs is the amount of energy that is left in them. Their charge levels affect the risk for a battery catching fire (loss of control) while they also may increase the difficulty of regaining control. For example, they generate more heat and flammable gas in a shorter period of time [33, 34]. Lower charge levels mean a more "friendly" fire behavior, with a significantly less severe burning behavior. This is one of the reasons why LIBs shipped according to UN regulations have less than $30 \%$ charge. A LIB that has burnt out completely, i.e. its flammable contents such as the electrolyte have been consumed, poses no fire risk. From a handling perspective, a preventative strategy before handling damaged LIBs is thus to either drain it of its energy or to ensure a complete burn out.

If the LIB pack is still operational or carries charge, there are some procedures available that can give guidance. EDUCAM, which is a knowledge and training organization for automotive industries in Europe, has developed such guidelines [35]. According to them, the first measure in handling of EVs is to perform an assessment [35]. This assessment considers three things, namely the vehicle type, its condition and the potential hazards to determine whether the vehicle may be parked in a regular parking spot or whether it needs to be moved to a designated location to be secured. An overview of how the status or condition of the vehicle affects this decision making is shown in Table 1.

If an EV fulfils certain conditions in Table 1. Handling and safety guidelines based on the condition of a vehicle [35] and/or if its LIB has burned, sustained abuse or been damaged, then it must be isolated. This can be in the form of a designated location, as mentioned before. These locations should be kept away from structures, vehicles and combustible materials in case of reignition or delayed ignition [35, 36]. Damaged EVs or LIBs should never be stored in underventilated enclosed spaces. Vented gases could harm personnel within this space or accumulate to cause a gas explosion. The National Fire Protection Association (NFPA) [36] recommends that a vehicle containing a burned or damaged LIB is 


\section{Table 1 \\ Handling and Safety Guidelines Based on the Condition of a Vehicle [35].}

Action

1. Perfect working condition (no fault code history for powertrain and BMS)

AND

Undamaged chassis

2. Perfect working condition (no fault code history for powertrain and BMS)AND

Damaged chassis, structural integrity intact

3. Vehicle with a fault — warning light on (recorded fault codes for powertrain and/or BMS)

AND

Undamaged chassis

4. Vehicle with a fault - warning light on (recorded fault codes for powertrain and/or BMS)

AND

Damaged chassis, structural integrity intact

5. Vehicle with a fault — warning light on (recorded fault codes for powertrain and/or BMS)

AND

Damaged chassis, structural integrity affected

6. Vehicle with signs of water damage (submerged vehicle or amage due to ingress of rainwater)
The vehicle may remain in the regular parking sport until work on the vehicle can commence.
The vehicle must be moved to a designated location to be secured before work on the vehicle can commence.

stored at least $15 \mathrm{~m}$ from structures, combustible materials or other vehicles until the battery is discharged [37]. They also recommend monitoring the LIB casing temperature using a thermal imaging camera if possible. SAE International [38], a US based professional association and standards developing organization for engineering industries, advocates the following steps for storing damaged EVs [39]:

- Do not store the EV inside a structure until it has been inspected according to SAE J2990 procedures (available through purchasing only). Open the vehicle's windows/doors for ventilation of potentially dangerous gases. Do not expose the EV to rain or other precipitation if the LIB is ruptured.

- An open perimeter isolation is an area in which all sides of the damaged vehicle (including the battery system) are at least $15 \mathrm{~m}(50 \mathrm{ft})$ from combustible materials, structures, and other vehicles, see [40] for details.

- A barrier isolation is an area where the vehicle is separated from all combustibles, structures, and adjacent vehicles by a wall made of non-com- 
bustible material. If the wall encloses 3 of 4 sides of the vehicle the open side must be at least $15 \mathrm{~m}(50 \mathrm{ft})$ from the nearest combustible material. It is not recommended to fully enclose the damaged vehicle due to the possibility of delayed fire/reignition or venting of harmful or explosive gases.

Another step in securing the vehicle is to ensure that the LIB is completely isolated from the vehicle. Examples of such procedures are presented in Table 2. An EV will automatically disconnect the battery system from the powertrain based on a sensed level of impact or abuse of the LIB. In special cases it may be necessary to perform this disconnection manually.

Vehicles are often equipped with a $12 \mathrm{~V}$ battery to start the engine and power critical systems. This is even the case for full electric vehicles such as the Nissan Leaf for example [41]. Disconnecting the $12 \mathrm{~V}$ battery's ground cable, or its fuses, will then ensure that an already switched off vehicle will not start up again [34]. If this is not possible, disconnecting the high voltage system may be needed. This is not a simple procedure, however, due to the many different possible configurations and locations of the main voltage disconnect. Some general guidelines on safely disconnecting the high-voltage battery pack are summarized in Table 2. Guidance can also be found in, NFPA's Hybrid and electric vehicle emergency field guide [37] or emergency response guides provided by vehicle manufacturer's [42]. Note that these guidelines are primarily developed for and intended for first responders.

After successfully de-energizing the high-voltage system, safe working conditions on the high-voltage system are normally guaranteed. The built-in safety systems should mitigate any risk for contacting live parts or the chance for electrical

\section{Table 2}

General Guidelines on Measures to Be taken to Safely Disconnect the LIB.

SAE international [39]

1. Vehicle shall automatically shut itself down based a sensed level of impact

2. Turn the ignition switch or power button to the off position (assuming critical battery circuits are not damaged)

3. Cut or disconnect the $12-\mathrm{V}$ battery cables and the DC/DC converter's $12-\mathrm{V}$ cable, and/or

4. Remove the manual disconnect (high voltage main disconnect) as shown in the vehicle's emergency response guide.
Car recycling Netherlands (ARN) [43]

1. Mark the EV to inform nearby responders/personnel about work being performed on highvoltage systems

2. Put the EV in park-mode, remove the ignition key or deactivate it using the power button. Store the key at least $10 \mathrm{~m}$ from the EV

3. Disconnect the $12 \mathrm{~V}$ battery from ground

4. Remove the service disconnect plug of the highvoltage battery using electric insulating gloves. Always have the plug with you

5. Wait at least $10 \mathrm{~min}$ for the capacitators to discharge

6. Measure whether the voltage has dropped to $0 \mathrm{~V}$ using a suitable voltage detector 
arcing. It is very unlikely that these systems are not present in modern EVs. If, for some reason, such safety systems are not in place or no longer functional, then there are some additional measures that can be taken according to EDUCAM which relate to insulating and discharging high voltage components [35]. Identifying such lapses will likely be very challenging without the assistance of the vehicle manufacturer.

Finally, carefully consider the type of work that is being performed near LIBs. This includes the steps taken to remove the batteries from the damaged EV. Certain activities may generate sparks, expose the battery to mechanical crushing, or increase their temperature. Training systems and requirements on the qualifications of the personnel performing such critical tasks is one way to control and reduce this risk. In addition to this, emergency response guides for the vehicle that is being dealt and if needed the possibility to communicate with the vehicle manufacturter are of importance.

\subsection{Recovering from a Traction Battery Fire}

When hazardous events do arise, during handling or after a traffic accident for example, the focus shifts to recovery. In other words, trying to get control of the hazardous situation and limit any damage it may cause. Ideally, a battery fire would be suppressed before it causes further damage to the fuel storage of the vehicle and before it spreads to an adjacent vehicle or fuel source. When the vehicle is within a structure, e.g. a tunnel, parking lot or ro-ro space on board a ship, this can normally be achieved by sprinkler systems. As shown in [26], the fire threat posed by typical EVs, with LIBs ranging from $1 \mathrm{kWh}$ to $40 \mathrm{kWh}$, is like that of conventional vehicles. Fixed sprinkler systems designed to prevent fire spread between conventional vehicles, are thus most likely just as effective in limiting fire growth rate, reducing gas temperatures and scrubbing the air from combustion products in case of an EV fire. From this perspective, there is thus no need for a ban on EVs from such structures, if they are appropriately designed to deal with a fire in a conventional vehicle. However, they are unlikely to have any effect on the battery fire itself due to poor access to the seat of fire. Thermal activity within the battery may thus still result in large quantities of combustible and toxic gas to be released.

To achieve the extinguishment of a fire inside a LIB pack, direct access to the battery cells is needed [44]. Access to a LIB fire can be difficult because the modules and battery pack are compactly designed with a high tightness level (e.g. IP67). The battery packs could also be in places that are difficult to have direct access to. This was shown by, among others, the NFPA [45]. In their work, extinguishing EVs required thousands (roughly $1000 \mathrm{~L}-10,000 \mathrm{~L}$ ) of liters of water and a quenching time of $15 \mathrm{~min}-60 \mathrm{~min}$. By comparison, a conventional car fire is normally extinguished within $5 \mathrm{~min}$ [29]. This has led to some fire brigades resorting to other solutions such as dropping the entire EV into a container with foam suppressant [46]. After the battery pack had reportedly emitted smoke, responders were able to prevent further failure in this case. First, they isolated the damaged $\mathrm{EV}$, by removing it from the building in which it was located. If it caught fire, 
there was no material nearby to which it could spread, as is recommended by EDUCAM and SAE. Then, placing the EV in a container filled with suppressant further restricts any potential fire from spreading. A benefit from this method is that run-off of contaminated suppressant is prevented and allows for it to be collected and sent for destruction. Although the procedures above were successful in the end, they may not be the most effective. Better solutions are needed, for example for vehicles carrying precious cargo or at situations where passenger escape is difficult. For off-road assets or machines as well as industrial and heavy equipment, working within critical infrastructure or harsh environments, any fire can result in tremendous costs. In those cases, the LIB needs to have an inherently safe design.

\section{Internal Fire Suppression for Traction Batteries}

Today, fixed fire detection and suppression systems are common for heavy vehicles with combustion engine compartments. These systems have shown to limit the consequences of fire. Examples of this include the reconstruction of a fire involving two gas buses by the Swedish Accident Investigation Authority [47] as well as an investigation by the Australian Office of Transport Safety Investigations (OTSI) [48]. They found that without effective fire detection and suppression, achieved by fixed systems in the engine compartment, similar events could be catastrophic. Assuming that a LIB fire is detected and there is access to the inside of the LIB pack(s), integrating a fixed fire suppression system inside the LIB may prove useful in preventing (further) failure and recovering from a thermal runaway event, as well as providing time for evacuation. Andersson et al. [49] found that agents with a high heat capacity, such as water and low expansion foam, provide rapid cooling and fire extinguishment for a battery. Other agents they tested, such as high expansion foam and nitrogen gas, provided less cooling but could still extinguish the flames if introduced into the battery pack correctly. Note however that these tests considered LIBs on ships and thus large quantities of suppressant were available. The capacity of fixed suppression systems on road vehicles is much more limited, however.

\subsection{Test Setup}

Fire suppression tests were performed by RISE during 2019 on traction batteries for heavy vehicle applications shown in Fig. 8 [50]. The goal of these tests was to evaluate the performance and applicability of commercially available fixed fire suppression systems in controlling thermal events within this battery. Important parameters here are the limited amount of suppression agent available on the vehicle, the suppression system activation time and duration, and position of the nozzles.

For the purpose of these tests the traction battery was modified to fit a combination of dummy and live battery modules. Each live battery module contains 12 hard prismatic cells (anode/cathode: $\mathrm{C} / \mathrm{NMC}$, nominal voltage: $3.7 \mathrm{~V}$, rated capacity: $28 \mathrm{Ah}$ ). In all tests the state of charge was $100 \%$. The dummy battery 
modules were made of stainless steel, filled with sand, and sealed. Modifications include removal of other combustibles in the battery pack such as connection cables and feedthroughs. A small opening in the body of the battery pack was made to expose a battery cell directly to the gas burner. A photo of the initial test setup is seen in Fig. 8. The traction battery consisted of two layers. Early on it was determined that the risk for fire propagation from the upper to the lower layer was very low, hence the following tests were conducted using only the upper layer, as can be seen in Fig. 9.

Seven tests were performed as shown in Table 3, two free-burn tests, one external fire suppression test, and four internal fire suppression tests. Up to $13 \mathrm{~L}$ of suppressant was used for all suppression tests, as is typical for fire suppression systems installed on heavy vehicles. The commercially available systems that were considered both employ water-based suppression agents with less than $5 \%$ foam additives.

\subsection{Measurements}

Temperatures inside the battery pack were measured with type-K thermocouples. These thermocouples, seen in Fig. 10, were either welded to the modules to measure surface temperatures (TC1-TC13) or positioned to measure gas temperatures (TC14 and TC15) inside the battery pack. Those thermocouples measuring gas temperatures were positioned at the same height as those welded to the modules, at half the module height. TC1 was fixed to the traction battery surface from the inside, $5 \mathrm{~cm}$ below the opening for the gas burner. All thermocouples were positioned at the same spot for all tests, meaning that only 15 thermocouples were used in test 2-7.

The sides of the live battery modules consist of sheet metal, which is where the thermocouples were attached. The cell number closest to each thermocouple are also listed in Fig. 10. The gas burner was positioned so that the flame impinged on cell no. 6 of module no. 1 .

\subsection{Water Mist System}

The water mist system was considered during test 2 (mist 1) and test 3 (mist 2) and is shown in Fig. 11. The suppression agent was stored in and supplied by $6.5 \mathrm{~L}$ piston accumulators, each weighing $18 \mathrm{~kg}$. Full cone nozzles were used inside the battery pack with a flow rate capacity of $1.7 \mathrm{~L} / \mathrm{min}$ and a $60^{\circ}$ spray angle. According to the manufacturer, these nozzles produce a droplet size of approximately $50 \mu \mathrm{m}$ in diameter. Three nozzles were considered in mist 1 . These were connected to the $2 \times 6.5 \mathrm{~L}$ cylinders, whereas in mist 2 these three nozzles were connected to only one $6.5 \mathrm{~L}$ cylinder. In addition, a fourth nozzle was aimed at the initiating module and was connected to its own $6.5 \mathrm{~L}$ cylinder. The total amount of suppressant was thus the same in the two tests $(13 \mathrm{~L})$ yet the number of nozzles and their spray duration differed. For mist 1 this was about 3 min while for mist 2 these nozzles were active for $1.5 \mathrm{~min}$ while the fourth nozzle continued spraying for an additional $2.5 \mathrm{~min}$, i.e. $4 \mathrm{~min}$ in total. 


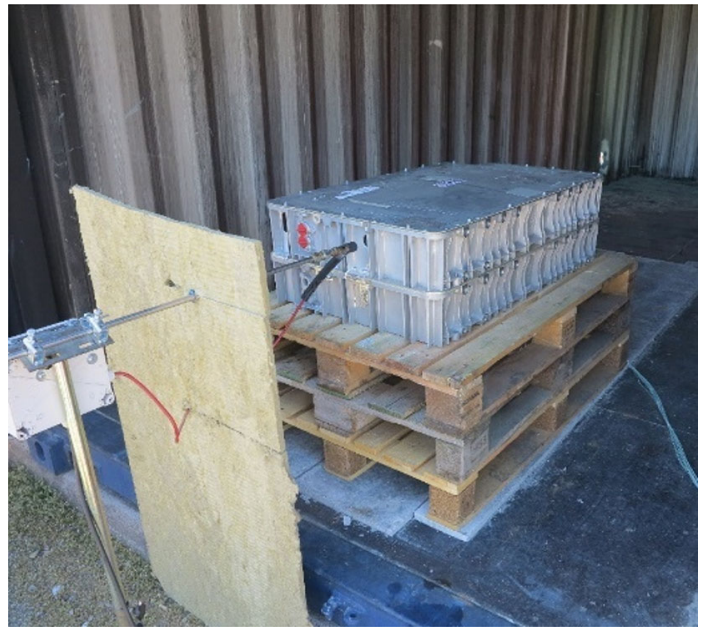

\section{Figure 8. The battery pack consisting of two layers placed inside the test container. The burner used to initiate thermal runaway is also shown.}

\subsection{Water Spray System}

The water spray system was considered during tests 5, 6, and 7 and is shown in Fig. 12. In this case, one single piston accumulator with $12.5 \mathrm{~L}$ of suppressant, weighing $32.2 \mathrm{~kg}$, was used to supply all nozzles. These nozzles were also full cone nozzles although with a smaller size and a high flow rate of $7.2 \mathrm{~L} / \mathrm{min}$ at an $80^{\circ}$ spray angle. In test 5 (spray ext), external suppression, a total of three nozzles were positioned $0.4 \mathrm{~m}$ above the traction battery. Two of them were aimed at the initiating side of the pack whereas a third one was aimed at its other end. In test 6 (spray 1) and test 7 (spray 2) these three nozzles were installed inside the traction battery. Two nozzles came loose in spray 1 which resulted in suppressant not making it into the pack. As such, the exact same setup was used for spray 2. This system released the agent in about $30 \mathrm{~s}$.

\subsection{Test Results}

Thermal runaway was initiated in one battery module by impinging on one of its cells with the flame of a gas burner. When thermal runaway was observed, as shown in Fig. 13, the gas burner was immediately shut off. In all fire suppression tests, the systems were activated $30 \mathrm{~s}$ after this initial thermal runaway event. This time was chosen as to simulate a delay between the fire starting and it being detected by a fire detection system. It took roughly 20 min to initiate thermal runaway, except for mist 2 where 54 min were needed due to a slight difference in the position of the impinging flame. Temperature recordings however showed nearly identical temperatures within the battery pack, regardless of pre-heating time. This suggests that the initial time period and temperature had minor influence on the scenario after the trigger cell went into thermal runaway. The tests were termi- 


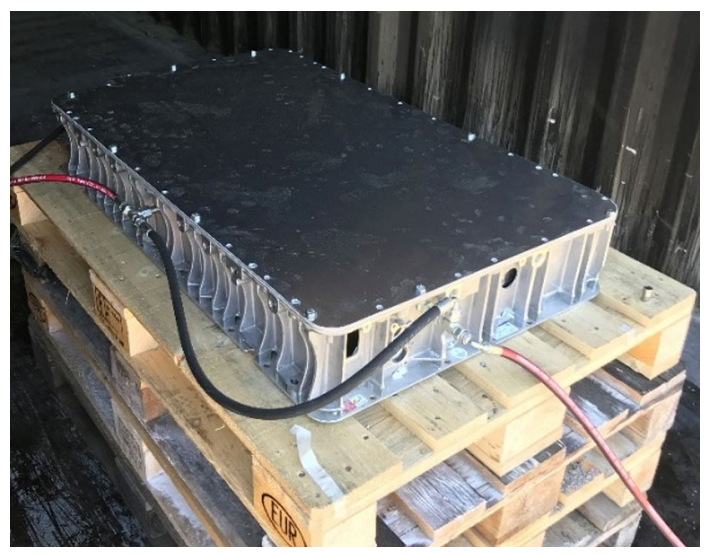

Figure 9. The second battery pack layer was removed for the remaining tests. Here the hoses connecting to nozzles inside the battery pack are also shown.

\section{Table 3}

Test Program.

\begin{tabular}{lllll}
\hline Test & Test setup & Suppression system & Agent application & Short name \\
\hline 1 & 2 Battery layers & None & - & ref 1 \\
2 & 1 Battery layer & Water mist & Internal & mist 1 \\
3 & 1 Battery layer & Water mist & Internal & mist 2 \\
4 & 1 Battery layer & None & - & ref 2 \\
5 & 1 Battery layer & Water spray & External & spray ext \\
6 & 1 Battery layer & Water spray & Internal & spray 1 \\
7 & 1 Battery layer & Water spray & Internal & spray 2 \\
\hline
\end{tabular}

nated when there was no longer any sign of thermal activity and recorded temperatures on the target module were stable and below $80{ }^{\circ} \mathrm{C}$.

External flames were visible in the reference tests, i.e. without fire suppression, for roughly $20 \mathrm{~min}$ after the initial thermal runaway event. When external or internal suppression were introduced however these flames were knocked out quickly after it activated, see Fig. 14. This is somewhat positive from a fire hazard perspective, as a potential initiating hazard is removed. However, activity proceeded inside the pack and a large amount of gas was produced. If allowed to accumulate in an enclosed space, there is a risk for a gas explosion due to sparks from the battery or other potential ignition sources.

Cooling inside the battery pack was insignificant if suppressant was applied externally to the pack, see Fig. 15a. This was also seen when succeeding thermal runaway events in the initiating module were studied, see Fig. 15b. The internal application of the suppressant had a positive impact on reducing the risk for fire 


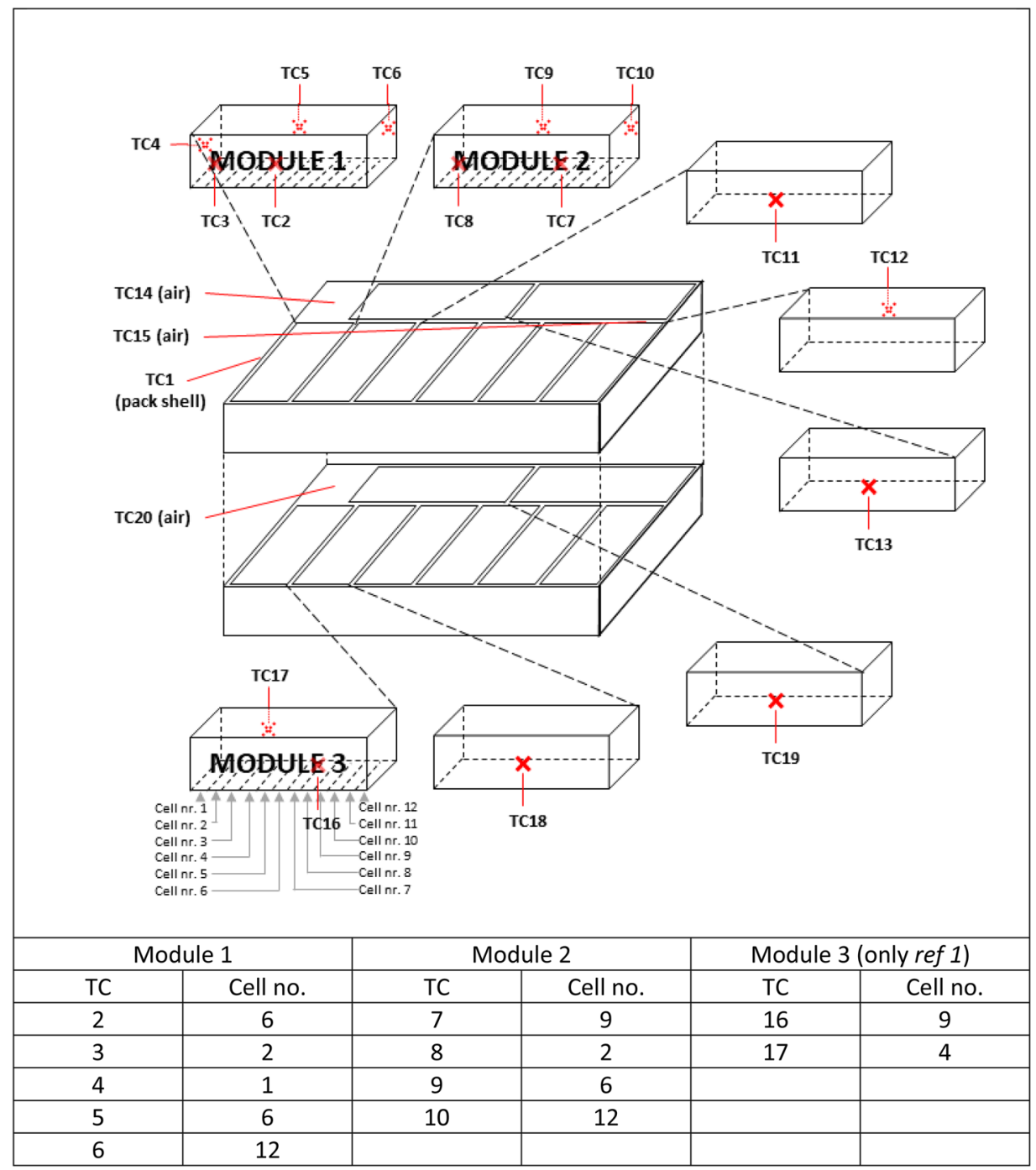

\section{Figure 10. Overview of measurement points and their position with respect to the live battery modules and cells.}

propagation between modules inside the tested battery pack. It also delayed how quickly the fire spread from one battery cell, or thermally propagated, to the next cell inside the initiating module. In addition, thermal runaway reactions were not triggered in all cells within this module either.

Thermal runaway did not initiate outside of the initiating module in any of the tests, i.e. there was no thermal runaway propagation from the initiating module to other modules within the battery pack. However, the registered temperatures without fire suppression were still high enough to cause irreversible damage. Consider- 
(a)

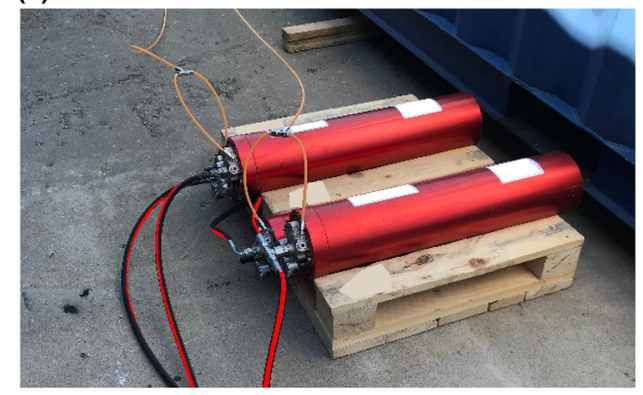

(c)

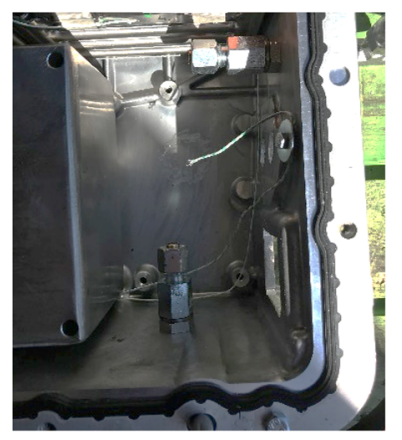

(b)

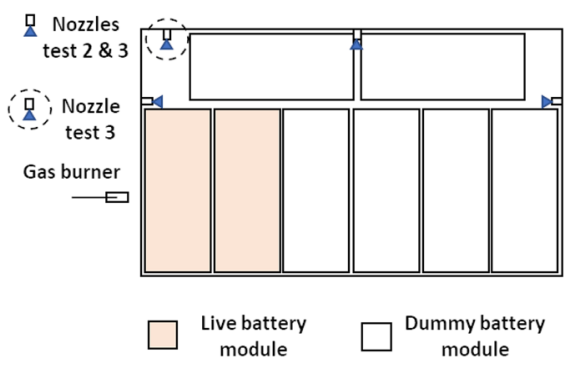

(d)

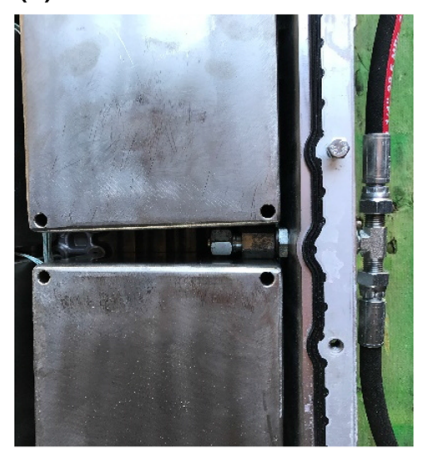

(e)

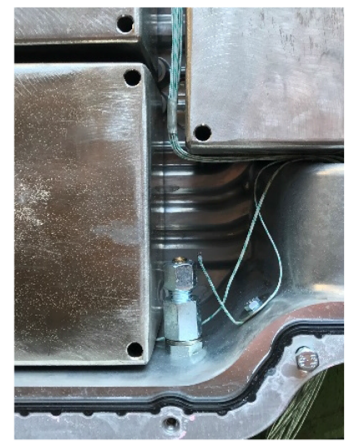

Figure 11. The water mist system considered for mist 1 and mist 2. (a) The two 6.5 L piston accumulators that supply the suppressant; (b) overview of the nozzle placements; (c) nozzle placement near the initiating module in mist 2; (d) nozzle placement between dummy modules; (e) nozzle placement on the far side of the traction battery.

ing a threshold temperature of $\sim 200{ }^{\circ} \mathrm{C}$ (temperature at the external surface of the module) for triggering thermal runaway, internal suppression systems a potential to stop thermal runaway propagation as seen from Fig. 16. It shows great promise that this can be achieved with only $13 \mathrm{~L}$ of suppressant as long as there is access to the contents of the traction battery. With the threshold value in mind, there will be no propagation from the initiating module to its neighbour, as represented by TC8 in Fig. 16.

While internal application of a water-based fire suppression system had a good potential to have a lasting cooling effect on the traction battery and to increase the chance of mitigating and preventing cascading failure, external suppression was not as effective. Still, it did knock out appearing flames, which means that this method is still useful in preventing fire spread from the battery to the surroundings. However, as it did not cool the traction battery, thermal activity was not halted, and large quantities of gas continued to be released. If these gases accumulate in enclosed spaces, such as the traction battery itself, there is a risk for explosion due to piloted ignition, e.g. sparks from batteries or hot surfaces. 
(a)

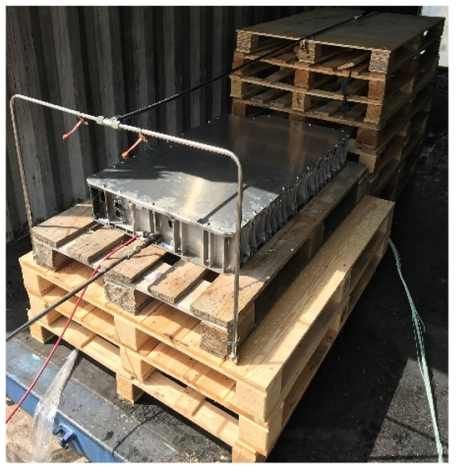

(b)
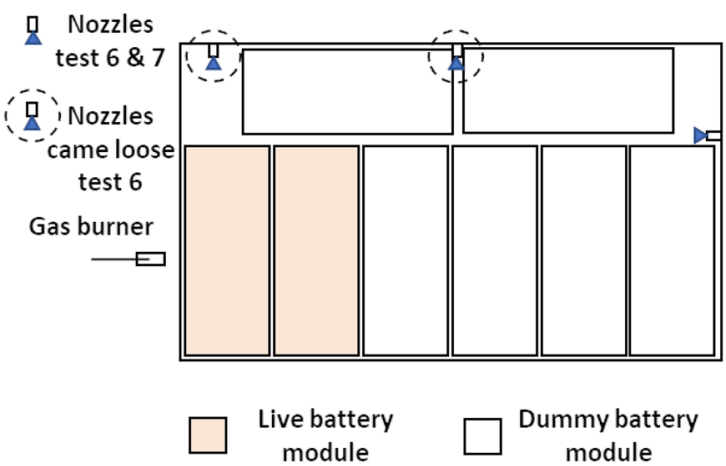

(d)

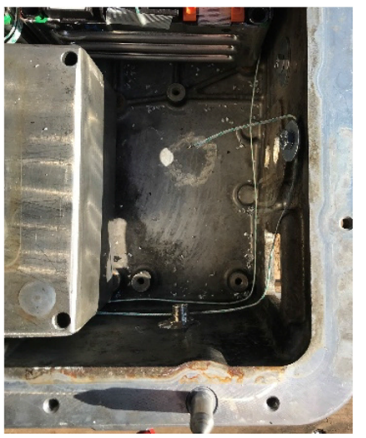

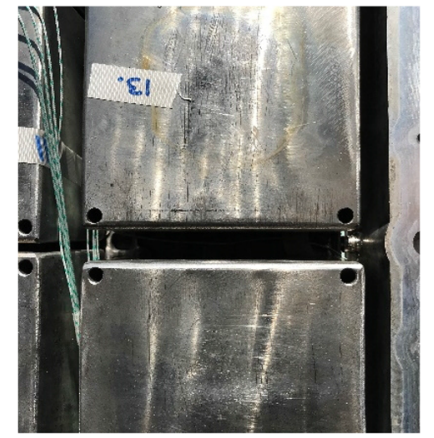

(e)

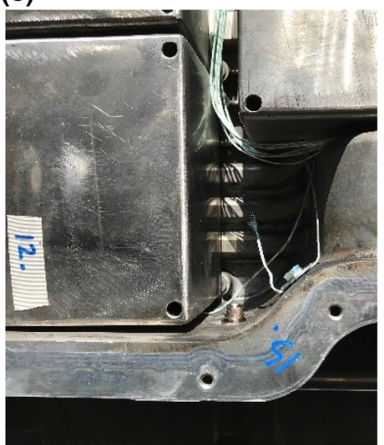

Figure 12. The water spray system considered for spray ext, spray 1 and spray 2. (a) The external fire suppression system; (b) overview of the nozzle placements; (c) nozzle placement near the initiating module; (d) nozzle placement between dummy modules; (e) nozzle placement on the far side of the traction battery.

Table 4 gives an overview and comparison of the results obtained in this study. The number of cells that went into thermal runaway is presented in the second column for each test. None of the tests were able to prevent thermal propagation throughout Module 1, however the internal fire suppression systems indicate a positive effect as some cells were saved. This trend was also found when looking at the average propagation rates. The average propagation rate refers to the time it takes for thermal runaway to propagate in order of successive failure, i.e. from the 1 st to the $3 \mathrm{rd}$, 3rd to the 6 th and finally 6 th to the last cell. These rates were reduced through consideration of internal fire suppression. The external fire suppression system had some effect, yet differences may be too small compared to the reference tests to be considered significant.

The water mist system performed slightly better at hindering cell to cell propagation than the water spray system. In addition, the water mist system was able to restrict temperatures on both sides of Module 2. The water spray system had a positive effect on the side facing towards Module 1 but was less effective at cool- 


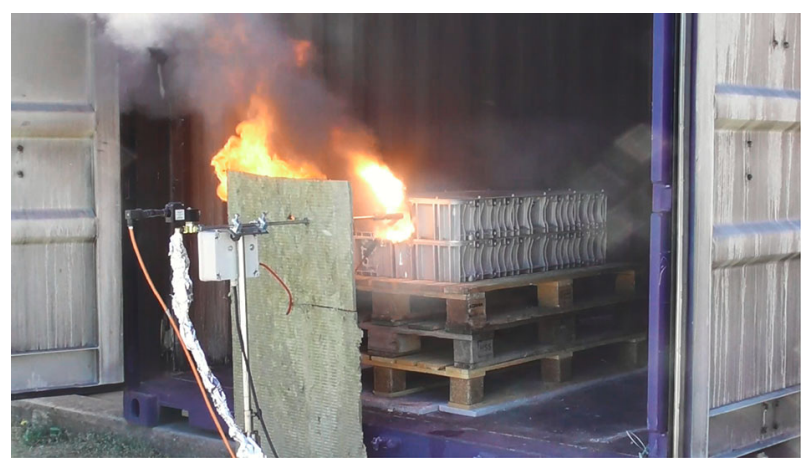

\section{Figure 13. Thermal runaway event during test 1 (ref 1 ). This occurred after the flame impinged on the initiating module for roughly $20 \mathrm{~min}$.}

ing the other side of Module 2. A reason for this could be the difference in release time of the agents. Specifically, $30 \mathrm{~s}$ for the water spray system and up to several minutes for the water mist systems. This possibly affected the amount of water that could be vaporized inside the pack. Another potential cause may be related to the agent contents and the difference in droplet size between a mist and a spray. However, the cooling effects of both systems were significant. For other scenarios and/or batteries, this difference might be crucial to avoid cascading failure in battery packs.

During the water spray tests it could be observed that large quantities of suppressant was thrown out of the battery pack, likely due to the short activation time and the limited space inside the battery pack. This suggests that a low flow rate and a longer release time is preferable, as was seen from the tests since the water mist system provided a stronger cooling effect throughout the traction battery. The test results do not show the minimum amount of suppressant needed to achieve a cooling effect, but $12-13 \mathrm{~L}$ achieved good results here. As a lot of suppressant was lost in the water spray tests, similar results would probably have been achieved if a smaller piston accumulator was considered.

There were no apparent benefits over introducing direct application of the fire suppressant onto the initiating module. It gave similar results in terms of propagation rates, surface temperatures and gas temperatures within the pack. These tests showed that internal total flooding of the battery pack, preferably at a low flow rates and long release times as mentioned, is most effective at hindering cell to cell and module to module propagation.

A post-test damage assessment was done 3 days after the fire tests were performed. This wait period was considered to ensure the traction battery was stable before it was opened. Analysing the two live modules after each test confirmed that the fire did not spread to the neighbouring module in any of the tests. One thing to keep in mind, however, is that there may still be a risk for cells (re)igniting after some time. If there are energized cells in the battery pack, that 

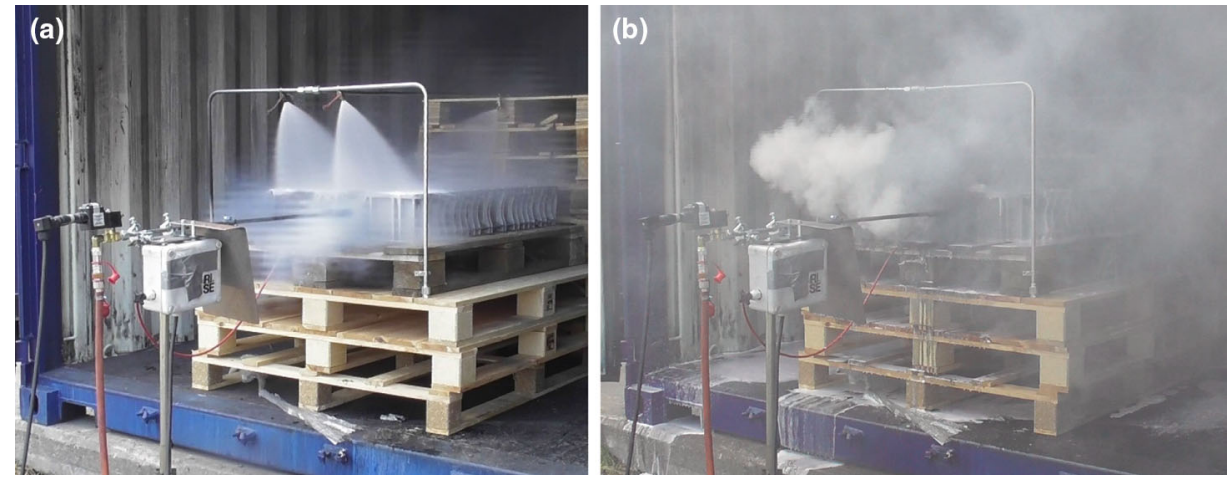

Figure 14. (a) External flames were quickly knocked out after the external fire suppression system activated; (b) succeeding thermal runaway events produced a lot of gas.
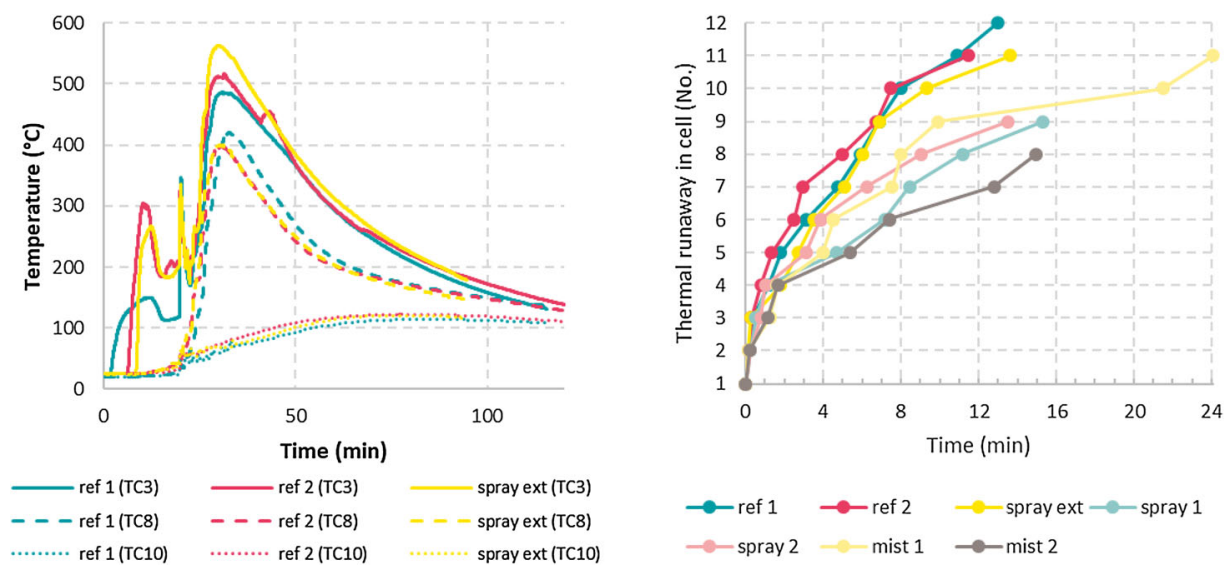

Figure 15. (a) Comparison of measured temperatures in the freeburn tests and external fire suppression; (b) number of cells inside the initiating module that went into thermal runaway (based on visual observations).

have sustained abuse or damage, this risk remains. For these tests, there was no reignition up to 3 days after the first test was performed.

\section{Conclusions}

This paper has presented different risk mitigation approaches that deal with preventing and recovering from hazards associated with lithium-ion batteries in road vehicles. This includes, traffic accidents and battery abuse conditions such as external fires that may penetrate the battery and internal fires that may arise 
TC3

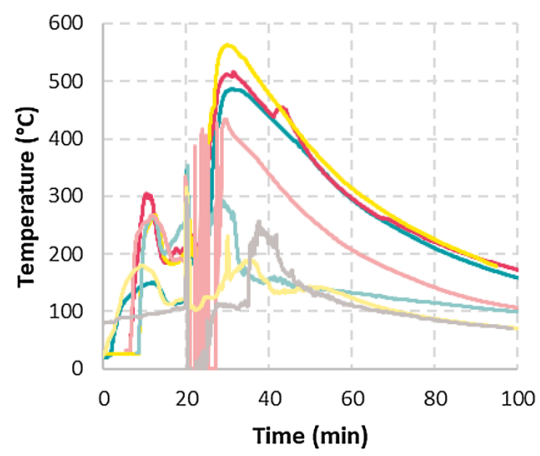

—ref $1-$ ref $2 \longrightarrow$ spray ext $\longrightarrow$ spray 1

$\longrightarrow$ spray $2 \longrightarrow$ mist $1 \longrightarrow$ mist 2

TC8

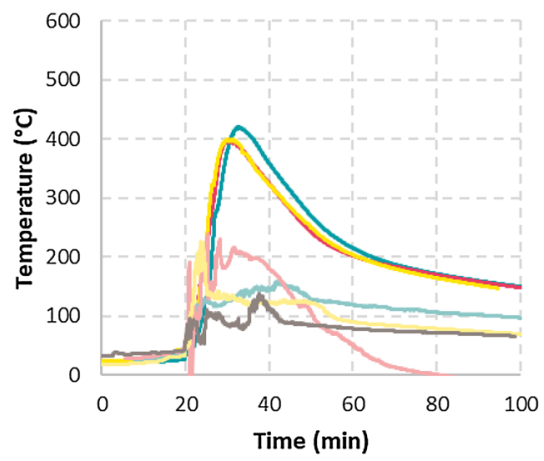

$\longrightarrow \operatorname{ref} 1 \longrightarrow$ ref $2 \longrightarrow$ spray ext $\longrightarrow$ spray 1

spray $2 \longrightarrow$ mist $1 \longrightarrow$ mist 2
TC6
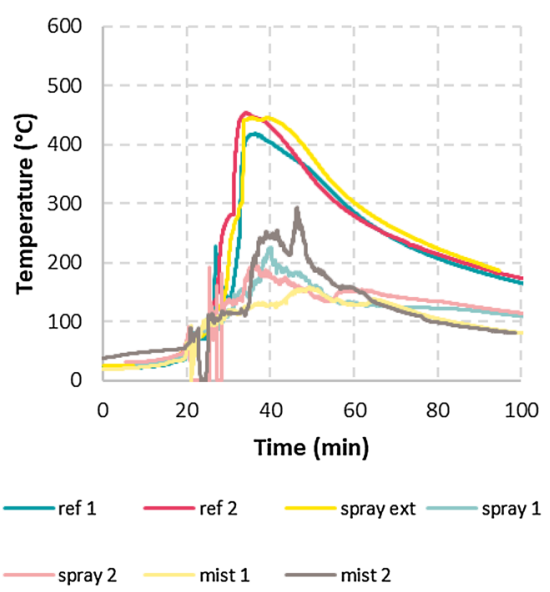

TC9
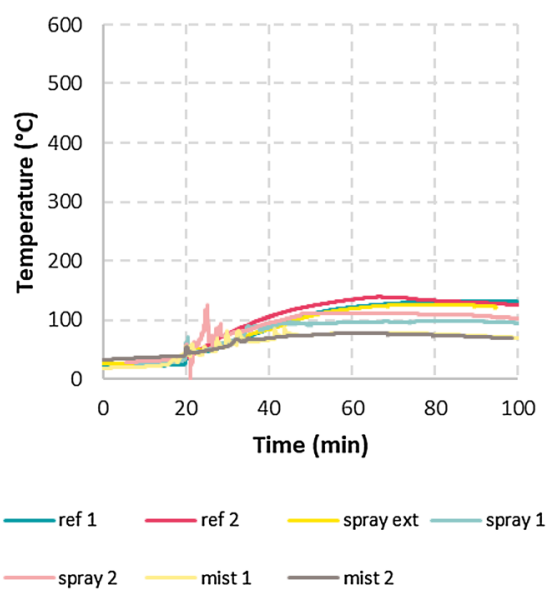

\section{Figure 16. Temperafures measured on the two live modules.}

inside the battery due to e.g. internal defects or external heat. Emphasis was placed on handling of electric vehicles after they have been exposed to significant abuse, as well as on fire suppression tests.

Regarding safe handling of damaged electric vehicles, different strategies have been investigated to prevent LIB packs from being affected, such as emergency response methods for isolating vehicles from combustibles and securing their highvoltage systems. Causes that may lead to thermal runaway and the appropriate mitigation methods were analyzed following a bow-tie risk assessment approach. This showed that although electric vehicles today do not appear to pose a different or greater fire threat than conventional vehicles, they are more difficult to gain control over. Specifically, they require more suppressant and time to than conven- 


\section{Table 4}

Summary of Results Obtained in this Study.

\begin{tabular}{|c|c|c|c|c|c|c|c|}
\hline \multirow[b]{2}{*}{ Test } & \multirow[b]{2}{*}{$\begin{array}{l}\text { Nr. TR cells, mod- } \\
\text { ule } 1(-)\end{array}$} & \multicolumn{3}{|c|}{$\begin{array}{l}\text { Mean propagation } \\
\text { rate for cells (cells/ } \\
\text { min.) }\end{array}$} & \multicolumn{3}{|c|}{ Mean temp 1st-last $+60 \min \left({ }^{\circ} \mathrm{C}\right)$} \\
\hline & & $\begin{array}{l}1 \mathrm{st}- \\
3 \mathrm{rd}\end{array}$ & $\begin{array}{l}3 \text { rd- } \\
6 \text { th }\end{array}$ & $\begin{array}{l}\text { 6th-- } \\
\text { last }\end{array}$ & $\begin{array}{l}\text { Mod. } 2 \text { front } \\
\text { (TC7/8) }\end{array}$ & $\begin{array}{l}\text { Mod. } 2 \text { back } \\
\text { (TC9/10) }\end{array}$ & $\begin{array}{c}\text { Air } \\
(\mathrm{TC} 14 / 15)\end{array}$ \\
\hline ref 1 & 12 & 8.57 & 1.07 & 0.61 & 248 & 97 & 88 \\
\hline mist 1 & 11 & 2.36 & 0.92 & 0.26 & 100 & 70 & 53 \\
\hline mist 2 & 8 & 2.61 & 0.48 & 0.26 & 98 & 70 & 44 \\
\hline ref 2 & 11 & 10.34 & 1.36 & 0.56 & 223 & 109 & 116 \\
\hline $\begin{array}{r}\text { spray } \\
\text { ext }\end{array}$ & 11 & 11.11 & 0.91 & 0.50 & 241 & 164 & 78 \\
\hline $\begin{array}{c}\text { spray } \\
1\end{array}$ & 9 & 5.66 & 0.45 & 0.37 & 141 & 88 & 82 \\
\hline $\begin{array}{l}\text { spray } \\
2\end{array}$ & 9 & 3.85 & 0.97 & 0.31 & $143^{\mathrm{a}}$ & 97 & 82 \\
\hline
\end{tabular}

The lowest values presented, and thus the most positive effect for the different evaluation criteria, are highlighted in bold values

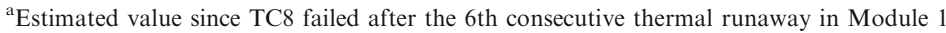

tional vehicles when traditional response tactics are used. Stranded energy after a fire is another challenge, where there have been instances of re-ignition occurring hours/days after the initial fire. To increase the safety of passengers and precious cargo, efforts are still needed to increase the safety level of traction batteries.

A novel fire suppression method was investigated as one method to tackle the challenge of suppressant an electric vehicle fire and mitigating reignition. This method considered integrating a commercially available fixed fire suppression systems into a lithium-ion battery pack as a means to prevent thermal runaway from propagating. This showed that introducing such systems inside the battery pack has a positive effect on fire safety as it limits peak temperatures and delays propagation. In turn this may increase the chance to gain control on a thermal runaway event and recover from it. It is however important to be wary of the gas explosion risk, as large quantities of gas may continue to be released after fire suppression has knocked out flames. To fully understand this risk, and to ensure good effect and design of the fire suppression system, tests are recommended to be performed on each unique battery installation before internal fire suppression is installed.

\section{Acknowledgements}

This project (No. 45629-1) was financed by the Swedish FFI-program (Strategic Vehicle Research and Innovation) which is a partnership between the Swedish government and the automotive industry. Partners within this project comprise of RISE Research Institutes of Sweden, Scania, Volvo Buses, SFVF (Swedish Associ- 
ation of Vehicle Workshops), Fogmaker International and Dafo Vehicle Fire Protection.

\section{Funding}

Open access funding provided by RISE Research Institutes of Sweden.

\section{Open Access}

This article is licensed under a Creative Commons Attribution 4.0 International License, which permits use, sharing, adaptation, distribution and reproduction in any medium or format, as long as you give appropriate credit to the original author(s) and the source, provide a link to the Creative Commons licence, and indicate if changes were made. The images or other third party material in this article are included in the article's Creative Commons licence, unless indicated otherwise in a credit line to the material. If material is not included in the article's Creative Commons licence and your intended use is not permitted by statutory regulation or exceeds the permitted use, you will need to obtain permission directly from the copyright holder. To view a copy of this licence, visit http://creat ivecommons.org/licenses/by/4.0/.

\section{References}

1. Nitta N, Wu F, Lee JT, Yushin G (2015) Li-ion battery materials: present and future. Mater Today 18(5):252-264

2. Cui H, Xiao G (2016) Fuel-efficiency technology trend assessment for LDVs in China: hybrids and electrification. The International Council on Clean Transportation, Copenhagen

3. Earl T, Mathieu L, Cornelis S, Kenny S, Ambel CC, Nix J (2018) Analysis of long haul battery electric trucks in EU. In: 8th Commercial vehicle workshop, Graz (2018)

4. International Energy Agency (2019) Global EV outlook 2019. International Energy Agency

5. EAFO (2019) AF fleet electricity: total number alternative fuels passenger cars. https:// www.eafo.eu/vehicles-and-fleet/m1. Accessed 22 Apr 2020

6. International Energy Agency (2020) Global EV outlook 2020: entering the decade of electric drive?

7. Plungis $\mathbf{J}$ (2018) How tesla and other EV battery fires challenge first-responder tactics. Consumer reports 2018

8. Freschi F, Mitolo M, Tommasini R (2018) Electrical safety of plug-in electric vehicles. In: IEEI industry applications magazine, pp 58-63

9. UNECE, UNECE R100 (revision 2) (2013)

10. Cadick J, Capelli-Schellpfeffer M, Neitzel DK, Winfield A (2012) Electrical safety handbook, 4th edn. McGraw-Hill, New York

11. Trattnig G, Leitgeb W (2014) Chapter 2: battery modelling for crash safety simulation. In: Automotive battery technology, Springer, Berlin, pp 19-35 
12. Sturk D, Hoffman L (2013) e-fordons Potentiella Riskfaktorer vid Trafikskadehändelse-En rapport baserad på e-fordons teknik, säkerhetsfunktioner och modern batterikemi, Rapport från FFI-projektet Räddningskedjan, SP Electronics \& Autoliv Development AB, SP Rapport 2013:58, Sweden

13. Xia Y, Wierzbicki T, Sahraei E, Zhang X (2014) Damage of cells and battery packs due to ground impact. J Power Sour 267:78-97

14. Bydauto (2013) BYD Fe battery, YouTube, 6 May 2013. https://www.youtube.com/wat ch? $\mathrm{v}=\mathrm{LIWq} 2 \mathrm{KecL} 3 \mathrm{c}$. Accessed 12 Dec 2018

15. Kesteloo H (2017) A new large fleet of 25 fully electric Volvo 7900 buses is going into operation in Norway. Electrek, 27 September 2017. https://electrek.co/2017/09/27/25-ful ly-electric-volvo-7900-buses-for-trondheim-norway/. Accessed 12 Dec 2018

16. VDL Bus and Coach (2016) Corporate presentation. https://ecv-fi-bin.directo.fi/@Bin/b d1a7ad8aeb7402e5be5118e09538b54/1538054339/application/pdf/214346/29_16_NEBI2_ Session7_Ojamo_VDL.pdf. Accessed 27 Sep 2018

17. Solaris Bus and Coach Electric buses: everything is changing. http://www.oradea.ro/fisi ere/module_fisiere/26259/1)\%20RO_Solaris_Electric_2017_RO-1.pdf. Accessed 27 Sep 2018

18. Optare (2014) Solo and Versa EV—all electric citybus vehicles. http://blogs.coventry.ac. uk/covid/wp-content/uploads/sites/11/2014/02/Optare-Solo-Versa-EV.pdf. Accessed 27 Sep 2018

19. Proterra (2019) Powering heavy-duty vehicles with highest performing batteries. https:// www.proterra.com/proterra-powered/battery-technology/. Accessed 1 Feb 2019

20. Green Car Congress (2015) CEC awards Proterra \$3 M toward electric bus manufacturing plant; Foothill Transit orders 13 more buses. https://www.greencarcongress.com/ 2015/04/cal-energy-awards-proterra-3m-toward-electric-bus-manufacturing-plant-foothil 1-transit-orders-13-more-buses.html. Accessed 28 Jan 2019

21. Ruijter AD, Guldenmund F (2016) The bowtie method: a review. Saf Sci 88:211-218

22. Bøe AS (2017) Fullskala branntest av elbil. SP Fire Research AS, SPFR-rapport A17 20096:03-01, Norway

23. Barth T, Swaim R (2018) NTSB investigations of EV fires. National Transportation Safety Board (NTSB), USA

24. National Transportation Safety Board (2019) Highway accident brief: single-vehicle run-off-road crash and fire fort Lauderdale, Florida, May 8, 2018. https://www.ntsb.go v/investigations/AccidentReports/Reports/HAB1908.pdf. Accessed 26 Aug 2020

25. Winkler S (2018) Final report - crash involving tesla model s-10400 South Bangerter Highway, South Jordan Police Department, South Jordan

26. Sun P, Bisschop R, Niu H, Huang X (2019) A review of battery fires in electric vehicles. Fire Technol

27. Ingason H, Li Y, Lönnermark A (2015) Tunnel fire dynamics. Springer, Borås

28. Long T, Blum A, Bress T, Cotts B (2013) Best practices for emergency response to incidents involving electric vehicle battery hazards: a report on full-scale testing results. The Fire Protection Research Foundation, Quincy

29. Reitan NK, Böe AG, Stensaas JP (2016) Brannsikkerhet og alternative energibærere: El- og gasskjøretøy i innelukkede rom. SP Fire Research AS, SPFR-rapport A16 20096-1:1, Norway

30. National Highway Traffic Safety Administration (2012) Chevrolet volt battery incident overview report, DOT HS 811 573, Washington DC, USA

31. NHTS Administration (2011) 2011 ORION ORION VII LI-ION HYBRID: recalls and safety Issues. https://www.nhtsa.gov/vehicle/2011/ORION/ORION\%252520VII\%25252 0LI-ION\%252520HYBRID\#recalls. Accessed 14 Jan 2019 
32. Xu C, Ouyang M, Lu L, Liu X, Wang S, Feng X (2017) Preliminary study on the mechanism of lithium ion battery pack under water immersion. In: ECS Transactions, New Orleans

33. Larsson F (2017) Lithium-ion battery safety: assessment by abuse testing, fluoride gas emissions and fire propagation. Chalmerst University of Technology, Gothenburg

34. Ouyang D, Liu J, Chen M, Wang J (2017) Investigation into the fire hazards of lithium-ion batteries under overcharging. Appl Sci 7:1-20

35. EDUCAM, Sectorale Norm EDU 100 V3.0: Veilig Werken aan HEV (Hybrid \& Electric Vehicles), Brussels: EDUCAM

36. National Fire Protection Association The leading information and knowledge resource on fire, electrical and related hazards. https://www.nfpa.org/. Accessed 26 Aug 2020

37. National Fire Protection Association (2014) Hybrid and electric vehicle emergency field guide. National Fire Protection Association, Quincy, MA, USA

38. SAE International. https://www.sae.org/. Accessed 26 Aug 2020

39. SAE International (2012) Surface vehicle recommended practice J2990, Hybrid and EV first and second responder recommended practice, Society of Automotive Engineers

40. US National Highway Traffic Safety Administration (2012) Interim guidance for electric and hybrid-electric vehicles equipped with high voltage batteries (law enforcement/emergency medical services/fire department, US Department of Transportation, DOT HS 811575

41. Nissan 2018 LEAF Fire Responder's Guide. https://www.nfpa.org/-/media/Files/Traini ng/AFV/Emergency-Response-Guides/Nissan/Nissan-Leaf-EV-2018-ERG.ashx.

Accessed 26 Aug 2020

42. National Fire Protection Association, Emergency Response Guides. https://www.nfpa.o $\mathrm{rg}$ /Training-and-Events/By-topic/Alternative-Fuel-Vehicle-Safety-Training/Emergency-R esponse-Guides. Accessed 21 Feb 2019

43. ARN, Veilig demonteren van hybride- en elektrische auto's, 23 September 2014. https:// www.ifv.nl/kennisplein/Documents/20140923-arn-veilig-demonteren-van-hybride-en-elek trische-autos.pdf. Geopend 20 June 2018

44. Petit Boulanger C, Thomaza J, Azmi B, Labadie O, Poutrain B, Gentilleau M, Bazin H (2015) A partnership between renault and french first responders to ensure safe intervention on crash or fire-damaged electrical vehicles. In: The 24th ESV conference proceedings (ESV2015), Göteborg, SE

45. Grant C (2014) Responding to electric vehicle battery fires. In: Proceedings from the third international conference on fires in vehicles, Berlin, Germany

46. Brandweer Midden- en West-Brabant, Facebook, 25 March 2019. https://www.faceboo k.com/BrandweerMWB/posts/2902012643145806. Accessed 29 May 2019

47. Swedish Accident Investigation Authority (2013) Slutrapport RO 2013:01, Brand med två biogasbussar i stadstrafik Helsingborg, Skåne län den 14 februari 2012, Sweden

48. OTSI (2013) Technical inspection findings, Fire involving Transdev Shorelink Bus MO1970, Mount Colah, 16 December 2011, Sydney, Australia

49. Andersson P, Arvidson M, Evegren F, Jandali M, Larsson F, Rosengren M (2018) Lion fire: extinguishment and mitigation of fire in li-ion batteries at sea, RISE Report 2018:77, Borås

50. Willstrand O (2019) Fire suppression tests for vehicle battery pack, RISE Research Institutes of Sweden, Borås, Sweden

Publisher's Note Springer Nature remains neutral with regard to jurisdictional claims in published maps and institutional affiliations. 